\title{
Eserden Müessire Seyr u Sefer: Carullah Efendi'nin Derkenar Notlarının Biyografisine Katkıları ${ }^{1}$ \\ Sami Arslan*
}

\section{Özet}

Modernleşme öncesi Osmanlı toplumunda bireylerin kendilerine dair anlatılarının bulunmadığı iddiası eski inandırıcılığını yitirmiş durumdadır. Carullah Efendi örneği, Osmanlı müelliflerinin derkenar notları vasıtasıyla otobiyografileri hakkında zengin bilgiler aktardıklarını göstermektedir. Dolayısıyla derkenar notlarının tarih yazımında kaynak olarak kullanılabileceğini söylemek mümkündür.

Anahtar Kelimeler: Carullah Efendi, derkenar notları, tarih yazımı.

\section{A Journey from Art to Artist: the Contributions of Carullah Efendi's Marginal Notes to His Biography}

\section{Abstract}

The claim that there was no self-person narrative in pre-modern Ottoman society has lost its former credibility. The example of Carullah Efendi shows that ottoman scholars convey rich information about their autobiographies through the notes on the margins. Therefore, it is possible to suggest that these notes may be used as a source in the history writing.

Keywords: Carullah Efendi, notes on the margins, history writing.

* Arş. Gör., Fatih Sultan Mehmet Vakıf Üniversitesi Edebiyat Fakültesi Tarih Bölümü, İstanbul/ Türkiye, sarslan@fsm.edu.tr

1 Makalenin son halini okuyarak eleştirileriyle katkı sunan Doç. Dr. Abdülhamit Kırmızı'ya müteşekkirim. 
Kitab'ın maddi boyutunu oluşturan zihnî arka planına, kitaba not düşen kitap sahibinin okur olarak nerede durduğuna ve bu notların kitap kültürüne dair ne söylediği v.s. sorularına cevap aramak amacıyla bir Osmanlı kadısı olan Carullah Efendi'nin hususi kütüphanesindeki "elyazmaları arasında sistematik araştırma” yapılmıştır. Berat Açıl'ın editörlüğünde yapılan bu araştırma kapsamında Carullah Efendi'nin kendi kütüphanesinde bulunan ve kendisi tarafindan okunan kitaplarındaki notları; İslâmî ilimler, aklî ilimler ile dil ve edebiyat ilimleri üç ana başlı̆̆ında 14 makalede değerlendirilmiştir. ${ }^{2} \mathrm{Bu}$ makalelerden bir tanesi ise derkenar notları ve muhtelif kaynaklar üzerinden Carullah Efendi'nin hayatını konu edinmektedir. ${ }^{3}$ Mezkur makalede derkenar notlarının yanısıra bir çok kaynak eser de kullanılmaktadır. Bizim kaleme aldığımız makalede ise Carullah Efendi'nin kütüphanesindeki sadece tasavvuf kitaplarının derkenarlarına düştüğü Arapça notların satır aralarından yola çıkarak yine sadece bu notların Carullah Efendi biyografisine/otobiyografisine dair ne söylediklerine bakılacaktır. Bugünkü anlamıyla akademik hassasiyetle düşülen bu kayıtlardan yola çıkarak Carullah Efendi'nin nisbî bir biyografisini tespit etmenin veya biyografisinde kalan kimi boşlukları bu notlar aracılığıyla doldurmanın ve hayatına dair yazılmış olan kimi bilgileri yine bu derkenar notları aracılığıyla tashih etmenin imkanı üzerinde durulacaktır. ${ }^{4}$ Bu imkanı denerken yukarıda da denildiği gibi onun biyografisinin inşasına katkıda bulunacak sair kaynaklardan sarf-1 nazar edecek yani sadece Carullah Efendi'nin elinden çıkmış olan tasavvufî derkenar notları üzerinden yola çıkarak icmâlen de olsa bir Carullah Efendi biyografisi ortaya çıkarmaya çalışacağız. ${ }^{5} \mathrm{Ki}$ bununla yapmak istediğimiz şey -Carullah Efendi'nin hayatına dair söylenmemiş şeyler söylemekten ziyade- derkenar notlarının başta ben anlatısı olmak üzere tarih yazımına ne derece katkı sağlayabileceğidir.

Meşâiru'ş-şu'arâ'nın satır aralarında Aşık Çelebî'nin otobiyografisinin izini süren Hatice Aynur, Aşık Çelebi'nin mezkur eserde -kendisi adına madde başı açmamasına rağmen- otobiyografisini nasıl inşa ettiğini araştırmaktadır. Aynur'un 16. y.y. şairi Aşık Çelebi için "metnin değişik bölümlerinde kendinden söz edip

2 Berat Açıl vd., Osmanlı Kitap Kültürü, Cârullah Efendi Kütüphanesi ve Derkenâr Notları, (Editör. Berat Aç1), Nobel, Ankara, 2015

3 Muhammed Usâme Onuş, "Bir Osmanlı Âlimi Cârullah Efendi’nin Terceme-i Hâli,” Osmanlı Kitap Kültürü, -Cârullah Efendi Kütüphanesi ve Derkenâr Notlart-, 2015, Ankara, s. 19-51

4 “Bu kayıtlar"dan kastedilen Carullah Efendi'nin kütüphanesindeki tasavvufî eserlerin derkenarlarında bulunan notlardır. Aksi halde sair kitaplardaki notlar da dikkate alınacak olursa Carullah Efendi'nin şimdiye değin bilinen biyografisinden daha tafsilatlısını elde etmek mümkündür. Öte yandan burada yapılmak istenen bir Carullah Efendi biyografyası inşa etmek değil, bilakis derkenar notlarından yola çıkarak (ayrıntının tarihi!) bunun imkanını sorgulamaktır.

5 Bu teşebbüs esnasında hayatına dair notlarda verilen bilgiler ile sair kaynakların çelişmesi durumunda da bu farklara işaret edeceğiz. Burada dikkate alınacak olan çalışma, en son yazılan olması hasebiyle DİA Veliyyuddin Carullah maddesi olacak ve mezkur kaynağa bundan sonra Veliyyuddin Carullah maddesi şeklinde atıf yapılacaktır. 
okuyucuların zihinlerinde kendi kişisel hikayesinin kurulmasına firsat verir"' şeklindeki tespitini bizim makalemizin konusu olan 17-18. y.yıl alimi Carullah Efendi için de söylemek mümkündür. Zira Carullah Efendi derkenar notlarında kendisinin ismine, künyesine, lakabına, medeni haline, eğitim hayatına, seyahatine, seyahatteki güzergahına, hocalarına, şeyhlerine, talebelerine, dostlarına, düşmanlarına, duygularına, kitaplarına ve tabii ki kütüphanesine dair zımnen ve sarahaten ama çoğunlukla dolaylı bilgiler vermektedir.

Öte yandan Carullah Efendi'nin metin/şerh/haşiye üzerine düştüğü notların kendilerinin de birer metin olduğunu, dolayısıyla bu notlara da metne bakılan nazarla bakmanın mümkün olduğunu söyleyebiliriz. Bu bağlamda mezkur notları -yansıtma gibi-çağdaş edebiyat kuramları üzerinden anlamlandırmanın imkanından söz edebiliriz. Fakat derkenar notlarını edebiyat kuramları üzerinden anlamlandırmak mümkün olmakla beraber Carullah Efendi'nin müderris, furuî (kad1) ve özellikle usûlî̀ olduğu gerçeğinden hareketle bu notları farklı bir metotla okuma teşebbüsünde bulunacağız. Zira fikıh usulünde özellikle Hanefi usulcülerine göre (ki Carullah Efendi de bir Hanefi kadısıdır ve aynı zamanda sıkı bir Hanefî' dir. ${ }^{8}$ ) lafzın manaya dört çeşit delalet etme biçimi vardır. Bunlar ise; lafzın/nassın doğrudan ibaresinden anlaşılan (lafizdan ilk etapta/doğrudan anlaşılan) anlam, lafzın işaret ettiğinden anlaşılan anlam, lafzın delalet ettiğinden anlaşılan anlam ve son olarak da lafzın iktizâ ettiğinden anlaşılan anlamlardır. Lafzın manaya/nassın şerî hükme bu türden delalet biçimlerine usul kitaplarında sırasıyla ibâretu'n-nas, işâretu'n-nas, delâletu'n-nas ve iktizâu'n-nas denilmektedir. Bunlardan birincisi nassin ibaresi demek olup bununla kastedilen lafizdan ilk etapta akla gelen/ilk etapta anlaşılan mana demektir. Yani nassın/lafzın kendisi için sevk edildiği, dile getirildiği anlamdır. İşaretu'n-nas, lafızdan ilk akla gelen mana olmayıp bilakis lafızdan ilk anlaşılan mananın lâzımı olan anlamdır. Delaletu'n-nas ise lafzın ibaresinden; ibaretu'n-nassı'ndan anlaşılan anlamın illetinde ortak olan manaya denilmektedir. Son olarak, kullanılan lafzın sahih olabilmesi için takdir edilmesi zaruri olan lafza/anlama ise iktizâu'n-nas, nassın-lafzın iktizâ

6 Hatice Aynur, Kurgusu ve Vurgusuyla Kendi Kaleminden Aşılk Çelebi’nin Yaşamöyküsü, (Âşık Çelebi ve şairler Tezkiresi Üzerine Yazılar. ), İstanbul: Koç Üniversitesi, 2011, s.21

7 Molla Hüsrev'in fikıh usulünden kaleme aldığı meşhur eseri Mir'at'a haşiyesi vardır, O.M. I. 267

8 Notlarında kadılık yaptığını bize bildiren Carullah Efendi'nin sıkı bir Hanefî olduğunu söylemek mümkündür. Zira İhyâ-u ulumiddîn'de geçen Ebu Yusuf'un zekattan kaçınmak için senenin sonunda malını hanımına hibe ettiği ve daha sonra da hanımından bu malı kendisine hibe etmesini istediğine dair "hukiye" ile rivayet edilen nota itiraz etmektedir. Carullah Efendi böyle bir şeyin mümkün olamayacağını bunu batıl bir görüş olduğunu ve taassubtan dolayı böyle bir rivayetin neşet ettiğini kaydetmektedir. Zira Ebu Yusuf bir müçtehittir ve Hz. Peygamber'den rivayet edildiğine göre müctedilerin hatasında dahi onlara bir ecir vardır. Notun devamında söz İmam-1 Azam'a getirilmekte ve İmam Şafi'nin “insanlar fıkıhta İmam Azam'ın '1yâlidir" sözüne atıf yapılmaktadır. 
yoluyla delalet ettiği anlam denilmektedir. ${ }^{9}$

$\mathrm{Bu}$ söylenilenlerin örnek üzerinden göstermek için Carullah Efendi'nin, Konevî'nin Kitâbu'n-nusûs'unun zahriyesine aldığı iki not üzerinden derkenar notlarının okuyucuya ne söylediğine bakılacaktır. Carullah Efendi bu notlardan tarihsiz olan birincisinde Ebu Abdullah Veliyyuddin Carullah imzasıyla şarihin eserinde referans olarak kullandığı kaynakların dökümünü vermektedir. Daha sonra bu dökümü yapılan kitapların Fatih Camii yanına kendisinin yaptırdığı vakıf kütüphanesinde bulunduğunu kaydetmekte ve mezkur şerhin şarihinin el-İznikî olabileceğini ileri sürmektedir.

Yine Ebu Abdullah Veliyyuddin Carullah imzalı ve 1151 tarihli ikinci notta ise zahriyesine not yazılan şerhin metni üzerine (Kitâbu'n-nusûs) yazılan başkaca şerhlerin künyeleri verilmektedir. Carullah Efendi notun devamında kendisinin bu elimizdeki şerhi mütalaa ettiğini ve eserde referans olarak kullanılan kaynaklardan da istifade ederek eseri tashih ettiğini belirtmektedir. Carullah Efendi son olarak başka bir nüsha olmadığı için mütalaa esnasında nüsha karşılaştırması yapamadığını, fakat Allah'ın kendisine bir nüsha [daha] ihsan etmesi durumunda (ve in teyessera lenâ nüshatun uhrâ...) karşılaştırma yaparak yeni bir okuma yapmak istediğini belirtmektedir. ${ }^{10}$ Az önce bahsedilen delalet biçimlerinin 1şı̆̆ında -tafsilalatına girmeden- bu iki nottan aşağıdaki tespitlere ulaşmak mümkündür:

1. Her şeyden önce biz bu notlardan Carullah Efendi'nin 1151 yılında hayatta olduğunu öğrenmiş oluyoruz.

2. Onun ismi Veliyyuddin, künyesi Ebu Abdullah lakabı ise Carullah'tır.

3. Ebu Abdullah künyesini kullandığına göre hayatında en az bir defa evlenmiştir ve en az bir erkek çocuğu vardır.

4. İlk erkek çocuğunun ismi Abdullah'tır.

5. En az bir sefer bulunduğu şehrin (Konstantiniyye) dışına seyahati olmuştur. Carullah lakabını kullanmasından seyahat ettiği bu yerin Mekke olduğunu anliyoruz.

6. Mekke'de uzun süre kalmıştır, zira aksi halde Carullah lakabını alamamas1 gerekirdi. Malumdur ki sadece umre veya hacc için Mekke-Medine'ye gidenlerin böyle bir lakapla anılması söz konusu değildir.

7. Carullah Efendi İstanbul'da (Konstantiniyye) Fatih Camii'nin yanında bir vakıf kütüphanesi kurmuştur ve bu kütüphaneye kendisi kitap vakfetmiştir. $\mathrm{Bu}$ vakfedilen kitaplar arasında dolayısıyla kütüphanesinde tasavvuf literatüründen eserler bulunmaktadır. 
8. Kütüphane kuracak ve bu kütüphaneye kitaplar vakfedecek durumda olduğuna göre hayatının en azından bir dönemini iktisadi açıdan rahat geçirmiştir.

9. Çok istemesine rağmen elimizdeki eserin ikinci bir nüshasını henüz temin edememiştir. Bunu da hayatının son dönemlerinde, daha öncesine nisbeten iktisadi bir sıkıntı içinde olduğuna haml etmek mümkündür.

10. Bu notlar bize Carullah Efendi'nin ahir ömrüne dair de fikir vermektedir. Zira ikinci notu attığ tarih olan 1151 Carullah Efendi'nin vefat ettiği yıldır. Seksenli yaşlarında olan Carullah Efendi'nin yazdığı bu notlar daha genç yaşlarında yazdığı notlardan yazı stili ve üslup açısından farklılık arzetmemektedir. Bu da en azından bu tarihte O'nun hâla dinç olduğunu, elden ayaktan düşmediğine işaret etmektedir.

11. Bir diğer husus ise Carullah Efendi'nin yaşama isteği ve kitaplara duyduğu tutkudur. Zira en az seksen yaşında olmasına rağmen Allah'tan kendisine mukâbele ile okumak için elindeki bu eserin ikinci bir nüshasını ihsan etmesini istemektedir.

12. Carullah Efendi "kitap"1 ihsan edilmiş bir nimet olarak görmektedir. Zira elindeki nüshanın ikinci bir nüshasının kendisine henüz Allah tarafından müyesser kılınmadığını fakat böyle bir beklentisinin de olduğunu kaydetmektedir. Ayrıca elindeki nüshadan bahsederken kendisine bunun müyesser kılınmış olduğunu söylemesi de bunu teyit etmektedir.

13. Carullah Efendi ulemayı kendi arasında sınıflandırmaktadır. Zira notlarda künyesini verdiği müellifler için muhakkik, fazıl, şeyh, allame gibi farklı sıfatlar kullanmaktadır.

14. Notların varağın aynı yüzünde ve yan yana aynı kimse tarafından atılmas1 zamanlarının da ilk etapta ayni olduğunu akla getirmektedir. Fakat her ne kadar notlardan bir tanesinin atıldığ 1 tarih kaydedilmemişse de notların farklı zamanlarda atıldığını biliyoruz. Zira birinci notta eserin müellifine dair tahmini bir bilgi verirken ikinci notta bu kararsızlık yerini kesin bilgiye bırakmıştır.

15. Bir Osmanlı alimi olan Carullah Efendi inşâ yapacak kadar Arapça bilmektedir.

16. Eserin referans kaynaklarını zikretmesi onun bu eseri okuduğuna delalet etmektedir. Fakat aynı nottan anlaşılan eserin müellifine dair bilgi sahibi olmaması ise birinci notu atarken eseri okuduğu noktasında soru işaretleri uyandırmaktadır. O halde en iyi ihtimalle birinci notu attığ tarihte eseri okumasa bile Keşfu'z-zunûn gibi bir kaynaktan eserin referanslarına dair edindiği bilgiyi paylaşmıştır. ${ }^{11}$

11 Nitekim Carullah Efendi hocamın hocasıdır dediği Katip Çelebi’nin Keşfu'-z-zunûn'una nadiren de olsa atıf yapmaktadır. 
17. Fakat ikinci notu aldığı esnada (1151) eseri kesinlikle okumuştur.

18. Carullah Efendi (en azından bu notu attığı tarihte) bu eseri tedris veya tederrüs etmemiş bilakis kendi başına okumuştur. Zira notta kullandığı fiil dtâle’tuhû'dur (طالعته) ve bu fiil "kitap" ile kullanıldığında okumak manasındadır."

19. Carullah Efendi kimi kitapları çapraz okumaya tabi tutmaktadır. Nitekim elimizdeki eseri okurken eserin referans olduğu kaynakları da okumuş bir bakıma eserin sağlamasını yapmıştır.

20. Carullah Efendi sorgulayan, eleştiren bir okurdur. Nitekim mütalaa ettiğini söylediği bu kitaba kimi müdahaleler yaptığını belirtmektedir. ${ }^{13}$

21. Yine kimi kitapları farklı nüshalarından okumakta, okumasa bile en azından böyle bir arzusu olduğunu dile getirmektedir. ${ }^{14}$

22. Carullah Efendi kimi kitapları birden fazla okumaktadır. Zira elindeki eseri okuduğunu fakat bir nüshasını daha temin etmesi durumunda karşılaştırarak tekrar okumak istediğini bildirmektedir.

23. Bu notların/lafizların delalet ettiği diğer bir anlam ise bahse konu nüshanın Carullah Efendi'ye aidiyetidir. Zira bu notlar her ne kadar temellük kaydı olmasa da kendisinin mütalaa ederek tashihte bulunduğunu söylemesi zımnen buna delalet etmektedir. Ayrıca bu eser içerisinde referans olarak kullanılan kaynak eserler benim kütüphanemde vardır ifadesi de mezkur nüshanın kendisine aidiyyetini örtülü olarak bildirmektedir. Son olarak “.. eğer Allah bana bu eserin bir nüshasını daha ihsan ederse" ifadesi de bu dediğimizi teyit etmektedir.

$\mathrm{Bu}$ notların yani lafizların ibaresinden/zahirinden, ilk etapta akla geleninden yani yazılış sebebinden anladığımız Carullah Efendi bahsedilen tarihte elimizdeki Kitabu'n-nusûs şerhini -kendi vakıf kütüphanesinde de bulunan başkaca kaynakların 1şı̆̆ı altında- mütâlaa etmiş olduğudur. Bu anlam lafzın yazılıș sebebi yani ibaretu'n-nass'1dır. Açıktır ki Carullah Efendi'nin bu notları düşmedeki birincil amacı budur. Notların Carullah Efendi'nin varlıklı olduğuna delaletinin ise işâretu'n-nas yoluyla olduğunu söyleyebiliriz. Zira kütüphane kurmak ve kitaba sahip olmanın -bugüne nispeten- masraflı olduğu bir dönemde kitap vakfetmek, vakfedenin varlıklı olduğuna işaret etmektedir. Mezkur notların (lafız-nas) Carullah Efendi'nin 1151 tarihinde hayatta olduğuna delalet etmesi ibarenin iktizasi yoluyladır. Zira açıktır ki yazmak için yazıcının hayatta olması gerekmektedir. Keza Carullah lakabı/lafzının onun seyahate çıkmış olduğuna delaleti de böyledir. Bu lakabı alabilmek öncesinde Mekke'de bir müddet iskan etmeyi iktizâa etmektedir.

12 el-Müncid fi'l-lügati ve'l-a'lâm, s. 470, Beyrut, Daru'l-meşrik 2000

صححته 13

14 ...ve in teyessere lenâ nüshatun uhrâ nükâbiluhâ.. 
Derkenar notlarını Carullah Efendi biyografisine 1şı1k tutacak gözle okumaya başlarken bu okumanın yukarıda yaptığımız gibi şekilde yani ibaretu'n-nass'ın mümkün olduğu yerlerde onunla, mümkün olmadığı yerlerde ise diğerleriyle olacağını göz önünde bulundurmalıyız

Carullah Efendi temellük kayıtlarında kendisinin ismini, künyesini, lakabını ve nisbesini zikretmektedir. Buna göre ismi Veliyyuddin, künyesi Ebu Abdullah, lakabı Carullah, nisbesi ise (Rûmî, sümme) el-Medenî’dir. İslam dünyasında kişinin evvela ismiyle, sonra künye/nesebiyle daha sonra lakabıyle ve en son da varsa nisbesiyle tanınması yaygın bir gelenektir. Bunların bir arada bulunması durumunda tertibin yukarıdaki gibi olması gerekir. ${ }^{15}$ Bununla beraber Carullah Efendi temellük kayıtlarında bu tertibe riayet etmemektedir. Bu durumu Cârullah Efendi'nin temellük kayıtlarındaki şiirsel tadı bozmamak istemesine bağlayabiliriz; fakat Carullah Efendi'nin derkenar kayıtlarında da aynı tertibi muhafaza ettiğini görüyoruz. ${ }^{16}$ Öte yandan Veliyyuddin Ebu Abdullah'ın tercih ettiği "Carullah" lakabı üzerine de bazı şeyler söylemek mümkündür. Abdurrezzak el-Mehdî lakaplar hususunda şunları söylemektedir:

[Abdulhayy Leknevî'den naklen] Irak fukahası lakap tercihinde genellikle Cessâs, Kudûrî, Tahâvî ve Kerhî gibi meslekî ve yöresel lakapları tercih etmektedir. Horasan ve Mâverâunnehir fukahası ise Şemsu'l-eimme, Fahru'l-İslam, Sadru'l-İslam gibi kendilerini tezkiye edici lakaplar kullanmayı tercih ederler. Bu, son zamanlarda çıkmış bir adettir, mutekaddim ulema bu tür şeylerden beridir... ${ }^{17}$

Şu durumda Carullah Efendi'nin isim ve lakabının da pek tasvip edilen türden olmadığını söylemek mümkündür.

Ebu Abdullah Veliyyudin Carullah'ın tasavvufî kitaplarına kaydettiği notların/kayıtların tarih aralıkları 1100 -1151'dir. Burada dikkati çeken husus Veliyyuddin Carullah'ın tasavvufi eserlerde 1100'den önce notlarının olmamasıdır. Halbuki kütüphanesindeki tasavvuf haricindeki kitaplarında mezkur tarihten önce de kendisinin imzasiyla notlar bulunmaktadır. Bu durumu onun tasavvu-

15 Künyenin ve nesebin isimden sonra gelmesi onların bir bakıma sıfat olmalarıyla alakalıdır. Malumdur ki sıfat tertip açısından da mevsufa tabidir.

16 Daha meşhur olmaları durumunda lakabın (el-Mesîh İsa b. Meryem örneğinde olduğu gibi) veya künyenin isme takdim edilmesi mümkündür, fakat Carullah Efendi'de bu durumun da olmadığını söyleyebiliriz.

17 el-Mehdî konuya dair başkaca alıntılar da yapmaktadır: [Ebu Abdullah el-Kurtubî'den naklen] Kitap ve Sünnet insanın kendisini tezkiye etmesini men etmiştir. Buna rağmen Mısırlılar ve Acemliler bu tür sıfatları kullanmaktadırlar. .. [İbnu'n-Nehhâs’tan naklen] Kimilerinin Muhyiddin, Giyaseddin, Nureddin gibi lakablarla bilinir olmaları ve bu lakapların tedavülde olması yalanın ne kadar da yaygınlaştığını gösterir. Bu tür lakaplar dinen bidat ve münkerdir.” Abdurrezzak el-Mehdî, el-Lubâb fî Şerhi'l-Kitâb (önsöz), Daru'l-Kitâbi'l-Arabî, Beyrut, 1996, s.14-15. 
fa intisabının Mekke veya Medine'de olduğu ve bu tarihten önce ise tasavvuf ve tasavvufî eserlere en azından notlandıracak derecede ilgi duymamasıyla yorumlayabiliriz. Nitekim aşağıda da geleceği gibi derkenar notlarından Carullah Efendi'nin Nakşibendî Tarikati'ne Mekke'de 1100'den sonra intisap ettiği bilinmektedir.

Cârullah Efendi'nin attığg temellük kayıtlarında ilk etapta iki durum dikkati çekmektedir. Bunlardan birincisi "Carullah" lakabının diğeri ise Ebu Abdullah künyesinin kullanılıp/kullanılmadığı kayıtlardır. Bu tefrikten yola çıkarak Veliyyuddin Ebu Abdullah'ın Carullah lakabını kullanmadığı yıllardan önce henüz Mekke'ye gidip yerleşmediğinei, keza Ebu Abdullah künyesini kullanmadığ dönemlerde ise henüz evlenmemiş olduğuna, evlense bile Abdullah isimli bir çocuğu olmadığı sonucuna varabiliriz. Temellük kayıtlarının izini bu açıdan sürdüğ̈̈müzde Carullah Efendi'nin Ebu Abdullah lakabını kullandığı en erken yılın 1104/1692 olduğunu görüyoruz. ${ }^{18}$ Şu durumda Carullah Efendi'nin en geç bu tarihten sonra evli olduğu sonucunu çıkartabiliriz. Veliyuddin' in Carullah lakabını kullandığı en erken tarih ise 1103 'tür. ${ }^{19}$ Elimizde başka kayıtlar olmaması durumunda Mekke'ye de en geç bu tarihte gittiğini söyleyebilmeliydik; fakat derkenar notlarında Cârullah Efendi'nin 1100 tarihinde Mekke'de olduğuna dair başkaca kayitlar mevcuttur.

Carullah Efendi bu kayitlarda kendisi için Rûmî, Mekkî ve Medenî nisbetlerini kullanmaktadır. ${ }^{20}$ Rûmî kaydı onun tevellüdüne (vatan-1 aslisine) işaret ediyor olmalıdır. Mekki ve Medeni ise aşağıda da geleceği gibi uzun yıllar buralarda kalmasından dolayıdır. Bu icmali bilgilerden sonra derkenar notları Carullah Efendi'nin kronolojisi hakkında -bir çoğu dolaylı yoldan- şunları söylemektedir:

1. 1100'de Mekke-i "Mükerreme"de ${ }^{21}$

2. 1103'de Medine-i "Münevvere" $\mathrm{de}^{22}$

3. 1104'te Mekke'de ${ }^{23}$

4. 1106' da Beytü'l-makdis'te ${ }^{24}$

5. 1107 'de Şam' da ${ }^{25}$

18 Süleymaniye Ktp. Carullah Efendi Koleksiyonu, 1458, vr. 1a

19 Süleymaniye Ktp. Carullah Efendi Koleksiyonu, 1469, vr. 1a

20 Tabi bunlara -her ne kadar kullanmasa da- İstanbûlî’yi de eklemek mümkündür.

21 Süleymaniye Ktp. Carullah Efendi Koleksiyonu, 1051, vr. 1a

22 Süleymaniye Ktp. Carullah Efendi Koleksiyonu, 1454, vr.1a

23 Süleymaniye Ktp. Carullah Efendi Koleksiyonu, 1582, 15

24 Süleymaniye Ktp. Carullah Efendi Koleksiyonu, 1580, vr.12

25 Süleymaniye Ktp. Carullah Efendi Koleksiyonu ,1051, vr.256b 
6. 1110'da Darusselam/Bağdat'ta ${ }^{26}$

7. 1111 'de Bağdat'ta ${ }^{27}$

8. 1112'de biladullaha yolculuğu sirasında Halep'te ${ }^{28}$

9. 1114'te Konya' da ${ }^{29}$

10. 1114'te tekrar Halep'te ${ }^{30}$

11. 1116/7/8/9 yıllarında tekrar Şam'da ${ }^{31}$

12. 1120 'de Konstantiniyye'de ${ }^{32}$

13. 7 Şevval 1126 'da Konstantiniyye'de ${ }^{33}$

14. 1135 'te Konstantiniyye' $\mathrm{de}^{34}$

15. 1138 'de Konstantiniyye'de ${ }^{35}$

16. 1140 'ta Konstantiniyye' de ${ }^{36}$

17. 1143 'de kadı olarak Halep'te ${ }^{37}$

18. 1147 'de Konstantiniyye'de ${ }^{38}$

19. 1150'de sürgün olarak Gümülcine'de ${ }^{39}$

20. 1150 'de Edirne'de ${ }^{40}$

26 Süleymaniye Ktp. Carullah Efendi Koleksiyonu , 1028, vr. 1a; 1072, vr. 1a; 1032, vr. 312a; 1072, vr. 76a

27 Süleymaniye Ktp. Carullah Efendi Koleksiyonu, 1015, vr. 439a; 992, vr. 1a; 571, vr. 1a;995, vr. 230b; 1015 vr. 439a'da temellük kaydının tarihi ve yeri olarak "1111 Daru'l-İslam" kaydı vardır. Fakat iki sebepten Dâru's-selam yerine Carullah Efendi'nin "kaleminden" sehven Daru'l-İslam çıkmış olmalıdır. Birincisi Carullah Efendi Daru'l-İslam'ı başka hiçbir yerde kullanmamakta, ikincisi ise onun 1111 'de Bağdat'ta olduğunu gösteren başkaca kayıttlar da bulunmaktadir.

28 Süleymaniye Ktp. Carullah Efendi Koleksiyonu, 1049, vr. 1b

29 Süleymaniye Ktp. Carullah Efendi Koleksiyonu, 1015-M, vr. 440a (Şam yolunu kullanacak hacı adayları, Anadolu»nun «sağ kol» denilen yolunu kullanırlardı. Bu sebeple bu yola «hac yolu» da denilmekteydi. Bu yol, Üsküdar-Gebze-Eskişehir-Konya- Adana-Halep güzergâhını kullanarak Şam〉a ulaşırd1.)

30 Süleymaniye Ktp. Carullah Efendi Koleksiyonu, 1071, vr. 127b

31 Süleymaniye Ktp. Carullah Efendi Koleksiyonu, 1015-M, vr. 457b

32 Süleymaniye Ktp. Carullah Efendi Koleksiyonu,1051, vr. 1a

33 Süleymaniye Ktp. Carullah Efendi Koleksiyonu, 1050, vr. 208b

34 Süleymaniye Ktp. Carullah Efendi Koleksiyonu,1032, vr. 312a

35 Süleymaniye Ktp. Carullah Efendi Koleksiyonu, Carullah 1582, vr. 15

36 Süleymaniye Ktp. Carullah Efendi Koleksiyonu, 1575, vr. 11a

37 Süleymaniye Ktp. Carullah Efendi Koleksiyonu, 1049, vr. 1a استكتبه ..من خط الثارح..

38 Süleymaniye Ktp. Carullah Efendi Koleksiyonu, 983, vr.1a ve diğer tevakkuf mühürlerinde

39 Süleymaniye Ktp. Carullah Efendi Koleksiyonu, 1034-1, vr. 92a

40 Süleymaniye Ktp. Carullah Efendi Koleksiyonu,1034, vr. 99b 


\section{1151 'de Konstantiniyye'de ${ }^{41}$}

Şunu hatırlatmakta fayda var ki Carullah Efendi'nin seyahatine dair kaydedilen bu tarihler -yukarıda da belirtildiği gibi- derkenar notlarının satır aralarında verilmiş bilgiler olup Carullah Efendi'nin bu notları yazmaktaki birincil amacı hangi tarihte nerede olduğunu bildirmek değildir. $\mathrm{Bu}$ notların satır aralarından görüldüğü üzere Carullah Efendi klasik Osmanlı uleması gibi mekan/zamanda oldukça hareketli bir hayat yaşamıştır. Bulunduğu şehirler arasında Mekke, Medine, Kudüs, Şam, Bağdat, Konya, Halep, Gümülcine ve Edirne bulunmaktadır. Bunlardan bazılarına ise birden fazla gitmiştir.

Veliyyuddin Carullah maddesinde Carullah Efendi'nin 1070 ve bir rivayete göre ise 1069 tarihinde doğduğu belirtilmektedir. Aşağıda geleceği üzere sürgüne gönderildiği Gümülcine'deki 1150 tarihli bir hatırasını anlatan Carullah Efendi kendisinin o vakit 80 yaşında olduğunu ifade etmektedir. Şu halde bu kayıttan yola çıkarsak Carullah Efendi 1070 yılında doğmuştur ve onun bu kaydı mezkur rivayeti yanlışlamaktadır. Tasavvufî kitaplarının derkenarlarında Carullah Efendi'nin doğumundan 1100 yılına yani 30 yaşına kadarki yaşamına dair herhangi bir kayıt bulunmamaktadır. Bu kayıtlardan öğrendiğimize göre Veliyyuddin 30 yaşında Mekke'ye gitmiştir. Mekke'ye hangi amaçla gittiğini bilemesek de Şakâik gibi biyografik eserlere bakarak bu seyahatinin ilmi kaygılarla olduğunu tahmin edebiliriz. Nitekim Şakâik'e yüzeysel bir bakış bile Osmanlı ulemasının y1llarca süren ilmî seyahatlerde bulunduğunu göstermektedir. Mesela aslen Halepli olan Sahn-1 Semân müderrislerinden Alâeddîn Ali Arabî Halep ulemasına "telemmüz eyledikten sonra" Bursa'ya gelerek Molla Gürânî'ye talebelik yapmış, daha sonra Fahreddîn Acemî'nin Edirne'de muidi olmuştur. Sonrasında Alaaddin Arabi Edirne'den Bursa'ya bu sefer müderris olarak dönmüştür. ${ }^{42}$ Şu halde Carullah Efendi'nin de bu seyahatlerin büyük çoğunluğunu ilmî endişeyle yaptığını söylemek mümkündür.

Yine Veliyyuddin Cârullah maddesinde Veliyyuddin'in 1101 veya 1102 y1lında Mekke'ye giderek burada yedi yıl kaldığ 1 ve bu esnada Kudüs, Şam, Halep, Hama, Nablus ve Bağdat'1 ziyaret ettiği ve nihayet 1110 yılında İstanbul'a döndügü belirtilmektedir. Aşağıda belirtileceği gibi derkenar notlarında ise durum bundan biraz daha farklıdır. Zira bu notlarda bize onun Mekke'de olduğunu haber veren 1100 ve 1104 tarihli iki kayda rastlıyoruz. Şu durumda Carullah Efendi'nin en geç 1110'da Mekke'de olduğunu biliyoruz ki bu da Carullah Efendi'nin belirtilen tarihte maddede belirtildiği gibi 32 değil 30 yaşında olduğu anlamına gelmekte-

41 Süleymaniye Ktp. Carullah Efendi Koleksiyonu, 1015-M,vr.439a. Buraya kadar verilen kimi tarihlerde mevize ve hendese kitaplarının derkenar notlarından da istifade edilmiştir.

42 Mecdî Mehmed Efendi, eş-Şekaiku'n-Nu'mâniyye ve Zeyilleri: Hadaikü'ş-Şekâik, 999/1591; neşre hazırlayan Abdülkadir Özcan, İstanbul: Çağrı Yayınları, 1989, s. 171-173 
dir. 1106'da Kudüs'te (Beytü'l-makdis) gördüğümüz Carullah Efendi'yi 1107'de Şam'da görmekteyiz. 1108-9 yıllarında onun nerede olduğuna dair kayıt bulunmamaktadır; fakat bu süreçte Mekke veya Medine'ye dönmüş olmalıdır. Veliyyuddin Carullah maddesinde Carullah Efendi'nin 1110 y1lında İstanbul'a döndüğ̈̈ belirtilmekte ve bu tarihten -hangi tarihte kadılık yaptığına dair bilgi vermeden- sonrasına dair ise sadece Edirne'de kadılık vazifesiyle bulunduğu bilgisi kaydedilmektedir. Fakat 1110 ve 1111 yılında atılmış derkenar notları/temellük kayıtları bize onun tekrar Bağdat'ta olduğunu haber vermektedir; nitekim Şevval ve Safer 1111 tarihli iki temellük kaydının yeri Bağdat'tır. ${ }^{43}$ Şu durumda asgari dokuz ay hatta daha fazla ${ }^{44}$ Bağdat'ta kalmış olması gerekmektedir. ${ }^{45}$ 1111'den sonra "Konstantiniyye"ye döndüğüne dair sarih bir bilgiye sahip değiliz; fakat 1114 tarihli iki derkenar/temellük kaydı/notundan birincisi Biladullah'a seyahat (rihle) esnasında "uğradığı" Konya'da ${ }^{46}$ (Konevî'nin kabrini ziyareti esnasında) diğeri ise Halep'te düşülmüştür. ${ }^{47}$ Carullah Efendi Konya'da uğradığı Konevi'nin halvete girdiği ve bu gün açık türbeler tipinin ayakta kalan tek örneği olarak bilinen yerin krokisini de vermektedir. "Halvet metinde zikredilen yer gibidir. Burası önünde kubbesiz bir kabir bulunan mescide bitişik bir yerdir. Üstü açık [ve Konevî' ye ait] olan bu kabre semadan zahiren ve batınen Allah'ın rahmeti yağmaktadır." ${ }^{\prime 4}$

$\mathrm{Bu}$ "seyahat esnasında uğrama" kaydı bize telmîhen Carullah Efendi'nin güzergahını da göstermektedir. Buna göre Carullah Efendi Mekke-Medine'ye "Şam yolu"ndan gitmiş olmalıdır. Sağ kol ve Hacc yolu da denilen bu güzergah Üsküdar-Gebze-Eskişehir-Konya- Adana-Halep güzergâhını kullanarak Şam'a ulaştırmaktaydı. Konya üzerinden Mekke-Medine'ye gitmekte olan Cârullah Efendi de bu yolu kullanmış olmalıdır. Notlarından1114'te Halep'te olduğunu bildiğimiz Carullah Efendi'nin 1114-6 arasında nerede olduğuna vakıf değiliz, bir sonraki notundan ise 1116'da Şam'da olduğunu anlıyoruz. Biladullah için yola çıktığını söylemesinden hareketle bu iki yıllık süreyi Mekke veya Medine'de geçirdiğini söyleyebiliriz. 1116-9 yıllarında Cârullah Efendi Şam'da 'mücâvir'dir. ${ }^{49} 1120$ 'de

43 “Tezkiretu'l-fevâid'in birinci cildi olan bu esere Veliyyuddin er-Rûmî' sümme el-Medenî, Şevval 1111'de Bağdat-1 Daru's-selâm'da Allah'ın izniyle sahip olmuştur." "Bu kitabı Veliyyuddin er-Rûmî sümme'l-medenî Daru's-selam'da Safer 1111'de yazdırmış ve bu nüshayı kendisinden yazılan nüshayla da bizzat karşılaştırmıştır”: Süleymaniye Ktp. Carullah Efendi Koleksiyonu,995, vr. 230b.

44 Nitekim eserin istinsahı için de makul bir zaman gerekmektedir.

45 Bunun yanı sıra şevval ile safer arasında Medine'ye tekrar gidip dönme ihtimali veya o arada başka yerlere gitme ihtimali de göz önünde bulundurulmalıdır.

46 Süleymaniye Ktp. Carullah Efendi Koleksiyonu, 1015-M, vr. 440a

47 Süleymaniye Ktp. Carullah Efendi Koleksiyonu, 1015-M, vr. 440a

48 Süleymaniye Ktp. Carullah Efendi Koleksiyonu, 1015-M, vr. 440a

49 Carullah Efendi'nin dört y11 Şam'da kalmasına rağmen kendisine Şam'a aidiyyetini bildiren Dımeşkî gibi nisbetler kullanmaması dikkati çekmektedir. 
ise Konstantiniyye'ye dönmüştür. Bu tarihten sonra 1126, 1135, 1138 ve 1140 tarihlerinde Konstantiniyye'de olduğunu gösteren kayıtlar bulunmaktadır, bu da 1120-40 arasında İstanbul'da olduğu ihtimalini akla getirmektedir. 1143 tarihinde attı̆g 1 derkenardan ise 73 yaşındaki Carullah Efendi'nin bu tarihte Halep'te kadı olduğunu öğreniyoruz. Carullah Efendi 1147 'de ise tevakkuf mühürlerinin de söylediği gibi İstanbul'dadır. 1150'de düştüğü notta kendisinin Gümülcine'den döndüğü zamanlarda bu derkenarı düştüğünü belirtmektedir. Carullah Efendi bu tarihte 80 yaşındadır ve Gümülcine bu yaşında onun sürgün yeridir. Bu derkenar notunun dışında şimsiye değin başkaca 'kaynak'ta belirtilmeyen bu bilgiye göre Carullah Efendi "mel'ûn ve maktûl”" kethudanın düşmanlığının akabinde zalim vezir tarafından buraya sürülmüştür. Carullah Efendi bu sürgün olayını metinde geçen "ruhani sesler işitenler" bağlamında dile getirmektedir:

Ben [zorunlu] ikametim olan Gümülcine'de yaşlıca bir zat ile tanıştım. O esnada 83 yaşında olduğunu belirten bu şeyh -ki y1l 1150 idi ve ben de o zaman 80 yaşındaydım- daha ilk karşılaşmamızda bana "benimle Allah rızası için kardeşlik/ arkadaşlık yapar mısın?" dedi, ben de kabul ettim. Daha sonra bana benim bu sürgünden kurtulacağımı müjdeleyerek "ey kardeşim ben [gaipten] sesler duyuyorum ve bu sesler bana senin bu sürgününün biteceğini söylüyor, aceleci olma, az sabret!" dedi. Ben işte bu şeyhle beraber burada beş aydan fazla zaman geçirdim." ${ }^{50}$

Carullah Efendi'nin notları hangi sebepten ötürü kethüdanın 'adâvetine' maruz kaldığına dair bir şey söylememektedir; fakat biz bu notlardan onun bu sürgün esnasında veya öncesinde Edirne'de kadılık yaptığını öğrenebiliyoruz. Zira yukarıdaki malumatın aktarıldığı varağın hemen arkasındaki derkenarın sonunda yine bu sürgün hadisesine değinir ve sürgününde rol oynayan kethüdanın öldürüldüğünü, kendisinin ise bu haberi Edirne'de kadı iken duyduğunu belirtmektedir. ${ }^{51}$ Dolayısıyla Carullah Efendi'nin kadı olarak sürgüne gönderildiğini söylemek mümkündür.

Derkenar notlarında bazen kişisel hayatının perdelerini aralayan Ebu Abdullah Veliyyuddin Carullah kimi arkadaşlarından ve karşılaştığı bazı hâdiselerden de bi'l-vesile bahsetmektedir. Örneğin "muhakkik ulemanın önde gelenlerindendir" dediği sûfî Şeyh Sadeddin Hamevî ile Beytu'l-Makdis ve Şam'da zaman geçirmişlerdir (ictema'a me 'ahûu. ${ }^{52}$ Bu bağlamda okuyucu Veliyyuddin Carullah'ın anlatıcı olduğu ve kendisinden sonraki okuyuculara ilginç anekdotlar paylaştı̆g 1 da olmaktadır.

فاجنمعت معه 50

51 Süleymaniye Ktp. Carullah Efendi Koleksiyonu, 1034, vr. 99b Burada Carullah Efendi'nin "ben Edirne'de kadı iken duydum" v.s. yerine "Edirne'nin kazasıyla imtihan olunduğum esو لقد وققت ذلك الكلام في ادرنة وقت ابتلائ بقضائها : nada duydum” demesi dikkat çekicidir

52 Süleymaniye Ktp. Carullah Efendi Koleksiyonu, 1092, vr. 124b 
“Dımeşku'ş-Şam'da olduğum zamanlarda Esmâu'l-husnâ zikri ile çok meşgul olurdum. Kıraat ile o kadar meşgul olurdum ki bir gün Gaffar ve Gafur isimlerini zikrederken bana bir hal ârız oldu ve "ey Gaffar ve Gafur olan [Allahım] benim zamanımda bulunan bütün insanları affet" dedim. Daha sonra Emevi Camii'ne giderek Yahya Aleyhisselam'ın kabrinin yanında virdimi çekmeye başladım. Seher vakti öncesiydi, Şeyhu'l-Harem es-Seyyid Halebî çıkageldi ve bana arkamdan ayağıyla şiddetlice vurdu. Kafamı çevirip bakınca kendisi beni tanıdı ve bu yaptığından utandı. Aslında [anladım ki] şeyh bana nâibu'l-kadı için hazırlanmış olan seccadeye farkında olmadan oturduğum için vurmuştu. Kendi kendime bu olayın bana bir uyarı olduğunu söyledim; bir uyarıydı, zira ben gece yaptığım duada Allah'tan zamanımda yaşayan bütün herkesi affetmesi için dua etmiştim, böylece Allah'ın böyle bir duaya razı olmadığını anlamış oldum" ${ }^{33}$

Derkenar notlarında Carullah Efendi'nin hocaları, talebeleri ve şeyhlerinin ayak izlerini de görürüz. Mesela Carullah Efendi Hacı İbrahim en-Nakşibendî el-İstanbûlî ismindeki zatın kendisinden Molla Fenarî'nin Miftâhu'l-gayb şerhini 1120 yılında Konstantiniyye'de okuduğunu belirtmektedir. Aynı zat Kuhustânî'nin Cami'u'r-Rumûz'unu da 1100 yılında fakat bu sefer Mekke-i "Mükerreme"de Carullah Efendi'den okumuştur. Carullah Efendi'nin burada kullandığ 1 fiil olan karae 'aleyye (قرأ علي) bilinçli bir tercih gibidir. Zira Carullah Efendi kendisinden mezkur kitabı okuyan bu zatın talebesi olmadığına ${ }^{54}$ veya olsa bile kendi akranı olduğuna veyahut da yanında hürmeti haiz birisi olduğuna vurgu yapıyor gibidir: "Nitekim bu zat arif, fazıl ve zeki bir kimseydi." 55

Bir Nakşî sâliki olan Carullah Efendi Şeyh Ahmed eş-Şirvânî "sümme”" el-Mekkî'nin mürididir. Kendisinin bu tarike intisabında daha önce bahsi geçen Hacı İbrahim en-Nakşibendî el-İstanbûlî vesile olmuştur: "Bu zat Nakşi Tarikatine intisap etmek hususunda bizim müşarikimiz idi." ${ }^{56}$ Carullah Efendi kâmil ve mükemmil olarak gördüğü şeyhi hakkında sitayişkâr ifadeler kullanmaktadır: "Altmış seneden fazla Mekke'de oturan bu şeyh ümmi, arif bir zat olup Nakşi Tarikatinde kendi zamanında misli olmayan bir kimse idi. Allah rahmet etsin" ketebehu ebu Abdullah Veliyyuddin Carullah, Konstantiniyye, sene $1151 .{ }^{57}$ Carullah Efendi'nin zahiri ilimlerdeki bir başka hocası ise İbrahim eş-Şehrozûrî, eş-Şehrânî el-Medenî'dir. Carullah Efendi ma'dûmun rü'yetini tartıştığı derkenarda hocasının bu konuda bir eser kaleme aldığını belirtmekte ve okuyucuyu hocasının bu eserine yönlendirmektedir. $^{58}$ Başka bir derkenarda ise Üstâdunâ el-allâme İbrahim el-Kürdî süm-

53 Süleymaniye Ktp. Carullah Efendi Koleksiyonu, 1013, vr, 85a

54 Nitekim talebelerinden bahsederken “..talebelerimizden bazısı” v.s. gibi ifadeler kullanmaktadır.

55 Süleymaniye Ktp. Carullah Efendi Koleksiyonu, 1051, vr. 1a

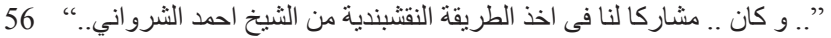

57 Süleymaniye Ktp. Carullah Efendi Koleksiyonu, 1051, vr. 1a

58 Süleymaniye Ktp. Carullah Efendi Koleksiyonu, 1034, vr. 5a 
me'l-Medenî diye tanıttı̆̆ 1 bir hocası vardır ki bu da az önceki zat olmalıdır. ${ }^{59}$

Bazense Carullah Efendi Şam'daki arkadaşı Şeyh Ali Bursevi hakkında anlattığ gibi enteresan anekdotlar paylaşmaktadır. Ihyâ'nın murâkabe bahsinde kimi mürâkiplerin mürâkabe esnasında neredeyse kendilerinden geçtiğinden ve etrafinda olup bitenden habersiz olduklarından bahsedilir ve bu hususa bir örnek verilir ${ }^{60}$ Carullah Efendi tam da bu hadisenin anlatıldığ 1 yerde araya girerek kendi başından geçen benzeri bir anekdotu ekleyerek Şam'daki arkadaşının hikayesini paylaşmaktadır. "Ben Dımeşku'ş-Şâm'da iken Şeyh Ali Bursevî isminde bir arkadaşım vardı. Bunun evi tıpkı burada, metinde zikredilen gibi çarşıya bakıyordu. Bir gün bulunduğu yerden yola bevledince insanlar onu kınadılar, o da binadan bakınca dışarıda kimseyi görmediğini söyleyerek kendisini savundu." ${ }^{61}$

Carullah Efendi'nin arkadaşlarının hepsi kimliklerinin teşhiri hususunda Şeyh Ali Bursevî gibi şanslı değildir, zira Carullah Efendi kimi derkenarlarda kimi arkadaşlarını sadece zamirle geçiştirmektedir. Gazali İhyâ' da insanlarla ihtilât etmeyip sadece Allah ile hem-hal olan insanlara örnek verirken Carullah Efendi araya girerek şahit olduğu başka bir hadiseyi anlatır. "Şam'da Emîru'lhacc Camii'nde benim Mekke'den tanıdığım bir adam vardı. Bu adam [da aynı metinde zikredilen kimse gibi] kendisine bir şey sorulmadıkça asla konuşmazd1." ${ }_{62}$ Derkenarlarda Carullah Efendi'nin kimi ilginç kişilerle olan tanıklığına da şahitlik ederiz. Muhammed b. Kutbuddin'in Şerh-u Kitâbi'n-nusûs'unda abdâl ve büdelâ'nın konu edinildiği yerde geçen "Büdelâ 40 kişidir, 22 tanesi Şam'da 18 tanesi ise Irak'tadır." hadisine düştüğü derkenarda kendisinin Şam'daki bu büdelâ/ abdallardan çoğuyla karşılaştığını (ictema 'tu me'a ekserihim) belirtmektedir. ${ }^{63}$

59 Süleymaniye Ktp. Carullah Efendi Koleksiyonu, 1042, vr. 50b

60 Gazali'nin anlattığı rivayet şöyledir. “Abdulvahid b. Zeyd isimli zata murakabe esnasında kendisini kaybeden bir kimse tanıyıp tanımadığı sorulduğunda O "az sonra bu sorduğunuz özellikte birisi gelecek" diye cevap vermiştir. Gerçekten de fazla zaman geçmeden içeriye Utbe isminde birisi girmiştir. Abdulvahid ona hangi yol üzerinden bu meclise geldiğini sorunca o da "falan falan güzergahtan geldim" der. Söylediği yol çarşıdan geçmektedir. Abdulvahid'in “peki yolda kimle karşılaştın?” diye sorması üzerine Utbe yol boyunca kimseyi görmediğini söyler. Halbuki bahsettiği güzergah çarşıdan geçmektedir."

61 Süleymaniye Ktp. Carullah Efendi Koleksiyonu, 981-M, vr. 429b

62 Süleymaniye Ktp. Carullah Efendi Koleksiyonu, 981-M, vr. 429b

63 Süleymaniye Ktp. Carullah Efendi Koleksiyonu, 1015-M, vr. 457b. "اجتمعت مع اكثر هم في مجاورتي "Carullah Efendi notun devamında büdelâ'nın Şam'da bulunacağını teyit eden başkaca rivayetler getirmektedir. 


\section{Sonuç}

$\mathrm{Bu}$ makale okuyucunun dikkatini üç meseleye temerküz ettirmeyi kendisine amaç edinmiştir. Bunlardan birincisi bireyselcilik/toplumsalcılık bağlamında tartışılagelen modernleşme öncesi Osmanlı toplumunda ben anlatısı olup olmadığı tartışmasına 18.y.yıl Osmanlı kadı ve sûfîsi Cârullah Efendi'nin ilmî kaygıyla düştüğü notlar üzerinden katkı sağlamaktır. Osmanlı tarihi kaynaklarında bireylerin kendileriyle ilgili anlatılarının bulunmadığı kabülünü sorguladığı (ve bunun böyle olmadığını gösterdiği) makalesinde Cemal Kafadar, "elyazmaları arasında sürdürülecek sistematik araştırma(ların) daha nice hatırat, rüya defteri, otobiyografi, esaret anıs1 ve şahsi mektup örneğini ortaya çıkaracağını" belirtmektedir. ${ }^{64}$ Nitekim Cârullah Efendi'nin tasavvuf kitaplarının derkenarlarına düştüğü ve sadece kendilerinden yola çıkarak Cârullah Efendi'nin hayatına dair birçok şeyi öğrenebildiğimiz bu notlar da Kafadar'ın tahminini haklı çıkarmaktadır. Zira Cârullah Efendi mezkur notların satır aralarına -tıpkı Aşık Çelebî'nin Meşấ'iru'ş-Şu'erâ' da yaptığı gibi- kendi biyografisini serpiştirmiştir. Öte yandan makalede vurgulanan diğer bir şey ise büyük anlatıların gölgesinde kalmış olan bu derkenar notlarının tarih yazıcılı̆̆ında kaynak olarak kullanılabileceğidir. Nitekim bu notlar bize sahibinin kişisel hayatına ve ilişkiler ağına dair birçok şey söylemesinin ötesinde -sürgüne gönderildiğini bildiren notta olduğu gibi- hayatı hakkında ilk defa öğrendiğimiz bilgilere ulaşmamızı da mümkün kılmaktadır. Öte yandan Carullah Efendi'nin tasavvuf dışında kalan kitaplarındaki derkenar notlarını da düşündüğümüzde sistematik şekilde atılmış derkenar notlarının tarih yazımı kaynağı olarak ne derece önemli olduğu da ortaya çıkmaktadır. Makalenin son çağrısı ise aynı zamanda kendileri de bir metin olan derkenar notlarını fikıh usulü metodoloji ile anlamlandırmanın mümkün olup olmadığı tartışmasınadır. Carullah Efendi otobiyografisine dâir makale boyunca verdiği malumatın neredeyse hiçbirisini hâtırâtını tescil etmek kaygısıyla kaleme almamıştır. Onun okuyucusu olarak biz bu bilgileri lafzın anlama çeşitli delalet yönlerinden yola çıkarak ulaşmaktayız. Özetle Cârullah Efendi'nin kadı ve fakih olmasından hareketle onun derkenara attığ bu notları yine onun zihin dünyasını oluşturan yöntemlerle yani fikıh usulündeki delalet yöntemleriyle okunmasının da mümkün olduğu görülmektedir. 


\section{Kaynakça}

Abdulvehhab Hallâf, İlm-i Usûli'l-fikh, Lübnan, 1956.

Abdurrezzak el-Mehdî, el-Lubâb fî Şerhi'l-Kitâb (önsöz), Beyrut, Daru'l-Kitâbi'l-Arabî, 1996.

Aç1l, Berat (editör), Osmanlı Kitap Kültürü- Cârullah Efendi Kütüphanesi ve Derkenâr Notları, Ankara, Nobel, 2015.

Aynur, Hatice, Kurgusu ve Vurgusuyla Kendi Kaleminden Aşık Çelebi'nin Yaşamöyküsü, (A̧şık Çelebi ve şairler Tezkiresi Üzerine Yazılar.), İstanbul, Koç Üniversitesi, 2011.

Bursalı Mehmet Tahir, Osmanlı Müellifleri, c. I, 267.

Kafadar, Cemal, Kim Var İmiş Biz Burada Yoğ İken, İstanbul, Metis, 2009.

Luvis b. Nikola el-Ma'luf el-Yesui Ma'lû , el-Müncid fi'l-Lügati ve'l-A'lâm, s. 470, Beyrut, Daru'l-Meşrik, 2000.

Mehmed Mecdi, eş-Şekaiku'n-Nu'mâniyye ve Zeyilleri: Hadaikü'ş-Şekaik, 999/1591, haz. Abdülkadir Özcan, İstanbul, Çağrı Yayınları, 1989.

Özcan, Tahsin, "Veliyuddin Cârullah", TDV İslam Ansiklopedisi, cilt 43, say1 38-40, İstanbul, 2013.

Süleymaniye Ktp. Carullah Efendi Koleksiyonu, 1013, vr. 85a

Süleymaniye Ktp. Carullah Efendi Koleksiyonu, 1015 vr. 439a

Süleymaniye Ktp. Carullah Efendi Koleksiyonu, 1015-M vr. 440a

Süleymaniye Ktp. Carullah Efendi Koleksiyonu, 1015-M vr. 457b

Süleymaniye Ktp. Carullah Efendi Koleksiyonu, 1015-M, vr. 439a

Süleymaniye Ktp. Carullah Efendi Koleksiyonu, 1015-M, vr. 440a

Süleymaniye Ktp. Carullah Efendi Koleksiyonu, 1015-M, vr. 457b

Süleymaniye Ktp. Carullah Efendi Koleksiyonu, 1015-M/277a

Süleymaniye Ktp. Carullah Efendi Koleksiyonu, 1028 vr. 1a

Süleymaniye Ktp. Carullah Efendi Koleksiyonu, 1032 vr. 312a

Süleymaniye Ktp. Carullah Efendi Koleksiyonu, 1034 vr. 99b

Süleymaniye Ktp. Carullah Efendi Koleksiyonu, 1034-1 vr. 92a

Süleymaniye Ktp. Carullah Efendi Koleksiyonu, 1042, vr. 50b

Süleymaniye Ktp. Carullah Efendi Koleksiyonu, 1049 vr. 1a

Süleymaniye Ktp. Carullah Efendi Koleksiyonu, 1049 vr. 1b

Süleymaniye Ktp. Carullah Efendi Koleksiyonu, 1051, vr. 1a 
Süleymaniye Ktp. Carullah Efendi Koleksiyonu, 1072 vr. 1a

Süleymaniye Ktp. Carullah Efendi Koleksiyonu, 1072 vr. 76a

Süleymaniye Ktp. Carullah Efendi Koleksiyonu, 1092, vr. 124b

Süleymaniye Ktp. Carullah Efendi Koleksiyonu, 1454 vr. 1a

Süleymaniye Ktp. Carullah Efendi Koleksiyonu, 1458 vr. 1a

Süleymaniye Ktp. Carullah Efendi Koleksiyonu, 1469 vr. 1a

Süleymaniye Ktp. Carullah Efendi Koleksiyonu, 1575 vr. 11a

Süleymaniye Ktp. Carullah Efendi Koleksiyonu, 1580 vr. 12

Süleymaniye Ktp. Carullah Efendi Koleksiyonu, 1582 vr. 15

Süleymaniye Ktp. Carullah Efendi Koleksiyonu, 571 vr. 1a

Süleymaniye Ktp. Carullah Efendi Koleksiyonu, 981-M, 429b

Süleymaniye Ktp. Carullah Efendi Koleksiyonu, 983 vr. 1a

Süleymaniye Ktp. Carullah Efendi Koleksiyonu, 992 vr. 1a

Süleymaniye Ktp. Carullah Efendi Koleksiyonu, 995 vr. 230b 